doi: $10.18484 / 2305-0047.2018 .3 .332$

G.P. KOTELNIKOV, YU.V. LARTSEV, I.G. TRUKHANOVA, A.D. GUREEV, O.V. FIRSTOVA, D.S. KUDASHEV

\title{
POSTOPERATIVE PROLONGED INFILTRATION ANESTHESIA FOR MULTIMODAL PERIOPERATIVE PAIN MANAGEMENT IN PATIENTS WITH HIP REPLACEMENT ARTHROPLASTY
}

\author{
Samara State Medical University, Samara, \\ The Russian Federation
}

Цель. Улучшить эффективность мультимодального периоперационного обезболивания у пациентов при тотальном эндопротезировании тазобедренного сустава за счет применения послеоперационной пролонгированной инфильтрационной анестезии области оперативного вмешательства.

Материал и методы. Проведен проспективный сравнительный анализ результатов лечения 78 пациентов, которым было выполнено первичное тотальное эндопротезирование тазобедренного сустава. Пациенты были разделены на две группы: в первой группе в послеоперационном периоде использовали продленную эпидуральную анальгезию, во второй группе применяли пролонгированную 24-часовую инфильтрационную анестезию области операции введением $0,2 \%$ раствора ропивакаина гидрохлорида с помощью микроинфузионной помпы с постоянной скоростью 8 мл/час. У всех пациентов анализировали выраженность болевого синдрома, уровень плазменной концентрации кортизола, уровень гликемии. Также оценивали расход тримеперидина и время начала активизации пациентов. Оценку проводили за 24 часа до операции, а также через 6 и 24 часа после нее.

Результаты. Через 24 часа после операции в первой и второй группах выраженность боли по шкале ВАШ составила $2,2 \pm 0,35$ и $1,5 \pm 0,42$ балла соответственно; уровень плазменного кортизола составил $768,5 \pm 45,8$ нмоль/л и 584,6 $\pm 54,2$ нмоль/л соответственно; уровень концентрации глюкозы в крови составил

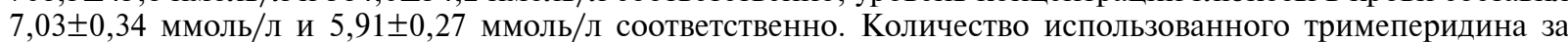
первые 24 часа после операции в первой и второй группах составило $38,6 \pm 2,95$ мг и 21,3 3,17 мг соответственно. Первое присаживание и вертикализацию пациентов в первой группе осуществляли через $24,8 \pm 2,4$ и $28 \pm 1,4$ часа, во второй клинической группе - через $4,5 \pm 0,5$ и $6,3 \pm 0,7$ часа соответственно.

Заключение. Применение пролонгированной инфильтрационной анестезии позволило на 46,7\% эффективнее купировать болевой синдром, на 55,2\% снизить количество требуемого тримеперидина в течение первых суток после операции и на 20,3土1,4 часа раньше начать активизацию пациентов по сравнению с продленной эпидуральной анестезией.

Ключевые слова: тотальное эндопротезирование, эпидуральная анестезия, инфильтрационная анестезия, ропивакаина гидрохлорид, микроинфузионная помпа

Objective. To improve the efficiency of multimodal perioperative pain management in patients in case of the hip replacement arthroplasty using postoperative prolonged infiltration anesthesia in the area of surgical intervention.

Methods. A prospective comparative analysis of the treatment results of 78 patients underwent the primary hip replacement arthroplasty was performed. The patients were divided into two groups: (1) the first group of patients was treated with prolonged epidural analgesia in the postoperative period, while (2) in the second group, the patients were treated with prolonged 24-hour infiltration anesthesia at the area of the surgical intervention by $0.2 \%$ of the ropivacaine hydrochloride solution, administered using microinfusion pump with a constant rate of $8 \mathrm{ml}$ per hour. All patients were assessed for intensity of the pain syndrome, plasma concentrations of the cortisol and blood glucose levels. Also, trimeperidine consumption rate and the start of patient's activity were assessed. The evaluation was conducted 24 hours prior to the surgical intervention, as well as 6 and 24 hours after.

Results. 24 hours after the surgery, the pain intensity scores assessed by the VAS were $2.2 \pm 0.35$ and $1.5 \pm 0.42$ points in the first and second clinical groups, respectively; the cortisol plasma levels 24 hours after the surgical intervention were $768.5 \pm 45.8 \mathrm{nmol} / 1$ and $584.6 \pm 54.2 \mathrm{nmol} / \mathrm{l}$ in the first and second clinical groups, respectively; the blood glucose levels after the surgical intervention were $7.03 \pm 0.34 \mathrm{mmol} / 1$ and $5.91 \pm 0.27 \mathrm{mmol} / 1$ in the first and second clinical groups, respectively. Trimeperidine consumption rates for the first 24 hours after the surgical intervention were $38.6 \pm 2.95 \mathrm{mg}$ and $21.3 \pm 3.17 \mathrm{mg}$ in the first and second clinical groups, respectively. The first sitting and complete verticalization of patients in the first group were performed in $24.8 \pm 2.4$ and $28 \pm 1.4$ hours, while in the second clinical group, these activities were performed in $4.5 \pm 0.5$ and $6.3 \pm 0.7$ hours respectively.

Conclusions. The use of the prolonged infiltration anesthesia allowed by $46.7 \%$ more effectively arresting pain syndrome, by $55.2 \%$ reducing trimeperidine consumption rate for the first 24 hours after the surgical intervention and by $20.3 \pm 1.4$ hours earlier starting activation of patients if compared to the prolonged epidural analgesia.

Keywords: hip replacement arthroplasty, epidural anesthesia, infiltration anesthesia, ropivacaine hydrochloride, microinfusion pump 
Novosti Khirurgii. 2018 May-Jun; Vol 26 (3): 332-339

Postoperative Prolonged Infiltration Anesthesia for Multimodal Perioperative

Pain Management in Patients with Hip Replacement Arthroplasty

G.P. Kotelnikov, Yu.V. Lartsev, I.G. Trukhanova, A.D. Gureev, O.V. Firstova, D.S. Kudashev

\section{Introduction}

Hip replacement arthroplasty now remains a traumatic surgical intervention and is accompanied by a pronounced postoperative pain syndrome. This is due to the fact that surgical intervention is performed on an abundant innervated receptor field, including the nerves of the periosteum, periarticular vascular-neural formations, as well as the branches of the femoral, sciatic, obturator, upper gluteus, lower gluteal and pudendal nerves [1, 2]. Injury of periarticular tissues during surgery induces the chain of mechanisms of the nociceptive and antinociceptive systems of the peripheral and central nervous system. In the case of inadequate anesthesia of the surgical site, the flow of afferent impulses from the lesion focus increases, resulting in overexcitation of segmental nociceptors of the posterior horns of the spinal cord. This, in turn, creates the conditions for lowering the threshold of excitability and increasing the area of the receptor fields (the phenomenon of "inflation"). Developing as a result of the above processes, the sensitization of nociceptive neurons (secondary hyperalgesia) may last for several hours or days after the end of the inflow of pathological impulses from the affected area.

Developing in response to a surgical trauma and inadequate relief of pain syndrome, metabolic and nonspecific inflammatory changes lead to organ and system dysfunction (insulin resistance, hypercatabolism, pulmonary dysfunction, myocardial ischemia, intestinal paresis, hypercoagulability) [3, 4]. That is why the most important task of anesthetic support for hip arthroplasty is not only the creation of adequate anesthesia in the intraoperative period, but also the blocking of nociceptive impulses from the perioperative area in the immediate postoperative period $[4,5]$.

One of the main requirements for modern anesthesia in hip replacement is the need to provide multimodal protection of a patient from the outcomes of surgical trauma in the organs and tissues. It is based on a differentiated approach to protecting the body's systems from a stress response caused by an operation trauma and consisting in a combination of both pathophysiological, metabolic (activation of the sympathetic nervous system, pituitary hormone hypersecretion, insulin resistance) and inflammatory (immune) responses. [6, 7]. In hip replacement arthroplasty, different variants of regional anesthesia (epidural, subarachnoid, spinal epidural and conductor blockades) are most widely used as an anesthetic. General and combined anesthesias, a combination of general anesthesia with a central blockade are less common. [8].

Today, the gold standard of postoperative analgesia in hip replacement is a prolonged epidural analgesia $[1,8,9]$. However, its use in the postoperative period may be associated with the risk of developing a number of complications and side effects, such as arterial hypotension, epidural hematoma in the case of using heparin and non-steroidal anti-inflammatory drugs, infectious complications, urinary retention. In addition, one of the main disadvantages of a prolonged epidural analgesia is the impossibility of early activation of patients - a factor of great importance, both in terms of preventing a number of complications and for the effectiveness of subsequent rehabilitation $[2,5]$.

An alternative to epidural analgesia in the postoperative period can be either a single or extended lumbar plexus blockade with long-acting amide anesthetics. However, there is no unequivocal opinion on the effectiveness of this method of anesthesia with the hip replacement arthroplasty. A number of authors point to the pronounced analgesic effect of the blockade of the lumbar plexus both in the back and inguinal access, other researchers did not receive this effect in any of the indicated variants of manipulation [10].

The use of the prolonged blockade of the femoral nerve with endoprosthetics of the hip joint suggested by a number of authors also seems inexpedient. The use of the method is associated with the risk of falls in patients due to paresis of the quadriceps femoris muscle. This adverse effect develops with the use of even $0.1 \%$ solution of ropivacaine hydrochloride and does not depend on the method and rate of its administration [11].

In our opinion the use of the scheme of multimodal postoperative analgesia with the use of postoperative prolonged infiltration anesthesia of the surgical intervention area is promising [12]. The appearance of microinfusion elastomeric micropumps at present makes it possible to expand the possibilities of this method of local anesthesia in the hip joint endoprosthetics.

Objective. To improve the efficiency of multimodal perioperative pain management in patients in case of the hip replacement arthroplasty using postoperative prolonged infiltration anesthesia in the area of surgical intervention. 


\section{Methods}

To achieve the goal, we proposed a prolonged infiltration of the field of the operative intervention with a $0.2 \%$ solution of ropivacaine hydrochloride, carried out with a microinfusion disposable pump ("Vogt Medical GmbH", Germany) V= $275 \mathrm{ml}$, with a constant injection rate of $8 \mathrm{ml} / \mathrm{h}$. The beginning of local administration of anesthetic was the end of the operation i.e. suturing the skin; duration of infusion -24 hours.

The effectiveness of the postoperative prolonged infiltration anesthesia was carried out on the basis of a prospective comparative analysis of the treatment results of 78 patients who underwent the primary cementless total hip replacement at the traumatologic and orthopedic departments 2 of the Clinic of Samara State Medical University during 2016.

Each patient gave the informed consent to participate in the study, which was carried out in accordance with the approved protocol, the ethical principles of the Helsinki Declaration of the World Medical Association (Seoul, 2008), the tripartite Agreement on Good Clinical Practice (ICH GCP) and the current legislation of the Russian Federation.

The criteria for including patients in the study were as follows: age - any; sex - any; absence of pregnancy; the presence of verified osteoarthrosis of the hip joint of the stage 3 or 4 (according to Kellgren and Lawrence, 1957); signed voluntary informed consent of the patient to participate in the study.

The criterion for non-inclusion of patients in the study was the presence of concomitant endocrine pathology, including diabetes mellitus, as well as alimentary-constitutional obesity, grade II or higher (BMI> $35 \mathrm{~kg} / \mathrm{m} 2)$.

All the observed patients were divided into two clinical groups by simple block randomization in the choice of the method of the postoperative anesthesia. Patients of both clinical groups were comparable by sex and age. The mean age of the patients was $64 \pm 2$ years $(\mathrm{M} \pm \sigma)$.

The first clinical group consisted of 38 patients. The postoperative analgesia was carried out by intramuscular (IM) injection of non-steroidal anti-inflammatory drugs (ketorolac tromethamine $30 \mathrm{mg} 3$ times daily IM) in combination with opioid analgesics (trimeperidine $20 \mathrm{mg} \mathrm{IM}$ as required) and prolonged epidural analgesia $(0.2 \%$ solution of ropivacaine hydrochloride epidurally at a rate of 6-8 $\mathrm{ml} / \mathrm{hr}$ with infusomat, duration of administration -24 hours after surgery).

The second clinical group included 40 patients. The protocol of the postoperative analgesia in this group also included an intravenous injection of nonsteroidal anti-inflammatory drugs (ketorolac tro- methamine $30 \mathrm{mg} 3$ times daily IM) in combination with opioid analgesics (trimeperidine $20 \mathrm{mg}$ IM on demand), but as an alternative prolonged epidural analgesia, these patients were given a prolonged infiltration anesthesia in the form of introduction into the surgical site within 24 hours after the operation of a $0.2 \%$ solution of ropivacaine hydrochloride, carried out with a microinfusion disposable pump ("Vogt Medical GmbH", Germany), with a constant rate of anesthetic injection of $8 \mathrm{ml} / \mathrm{hr}$.

The groups were comparable clinically by sex and age.

Surgical interventions for all patients were performed under the spinal anesthesia. Thirty minutes after premedication, a puncture of the subarachnoid space was performed under sterile conditions with the administration of a $0.5 \%$ solution of bupivacaine $20 \mathrm{mg}$. At the same time, the patients of the first clinical group were previously made to catheterization of the epidural space. All patients had an adequate spinal block. During the surgical intervention, a local anesthetic was not injected into the epidural space. The duration of the somatic-sensory block averaged $3.9 \pm 1.1 \mathrm{~h}(\mathrm{M} \pm \sigma)$, the operative intervention - $1.4 \pm 0.3 \mathrm{~h}(\mathrm{M} \pm \sigma)$.

For a comparative evaluation of the postoperative analgesia efficacy and evaluation of the severity of perioperative stress response, the Individual Card for the Evaluation of the Perioperative Stress Reaction in Total Hip Replacement was developed, according to which the results of the following clinical and laboratory tests were analyzed:

1. Assessment of pain intensity on a visual analogue scale (VAS), scores.

2. The level of plasma concentration of cortisol, nmol/l.

3. Level of plasma glucose concentration, $\mathrm{mmol} / \mathrm{l}$.

Also, as a quantitative criterion for assessing the effectiveness of the postoperative analgesia, the expenditure of the used opioid analgesic trimeperidine in milligrams was evaluated.

In addition, all operated patients were registered the time of the onset of motor activation in the form of their sitting in the bed and full verticalization in the form of standing up with support on the crutches, expressed in hours that had passed since the end of the surgical intervention. This parameter not only determined the effectiveness of the postoperative analgesia, but also acted as a kind of integrative qualitative criterion for achieving both the goal of the research and, in general, the goal of treating patients.

All clinical and laboratory parameters were determined 24 hours prior to the surgery, then 6 and 24 hours after the surgery. The amount of trimeperidine used was evaluated in total at the end 
of the first day after the operation.

\section{Statistics}

The results obtained are presented in the form of absolute and relative values, means with standard deviation. The significance of differences in quantitative data was assessed using Student's t-test, the Pearson's chi-squared test was used to estimate the difference in the shares. Critical values of the level of statistical significance in the verification of the null hypothesis were assumed to be $p \leq 0.05$. Statistical processing of the obtained results was carried out using the software package STATISTICA (Statistica for Windows, Release 6.1, StatSoft Inc., USA).

\section{Results}

The initial mean level of the pain intensity on the VAS scale in both clinical groups did not differ significantly and amounted to $3.6 \pm 0.57$ points in the first and $3.4 \pm 0.34$ points in the second clinical group, respectively. Six hours after the end of the operation, there was a significant difference in pain intensity in patients of the first and second clinical groups: in the first clinical group it was $2.9 \pm 0.34$ points; in the second $1.9 \pm 0.44$ points. By the end of the first day after the operation, the severity of the pain syndrome in the first clinical group was determined at $2.2 \pm 0.35$ points; in the second clinical group $-1.5 \pm 0.42$ points.

The dynamics of the severity of the pain syndrome according to the VAS scale is presented in Table 1.

Comparative analysis showed that the use of the prolonged infiltration anesthesia in the field of the operative intervention made it possible to reduce the pain syndrome more effectively by $46.7 \%$ compared with the prolonged epidural analgesia.

When assessing the dynamics of the plasma concentration of cortisol in the peripheral blood, the following was revealed. The initial cortisol indices in the first and second clinical groups were within the norm $(507 \pm 24.7$ and $517.3 \pm 30.8 \mathrm{nmol} / \mathrm{L}$, respectively). Six hours after the operation, there was a significant increase in the level of cortisol in the patients of the first clinical group to $876.1 \pm 76.8$ nmol/1 (72.8\% higher than baseline), compared with the second clinical group, in which the cortisol level was $676.5 \pm 54.6 \mathrm{nmol} / 1$ ( $30.8 \%$ higher than the initial value). 24 hours after surgery, the cortisol level decreased in both the first and the second clinical groups, but in the first group it continued to exceed the norm: $768.5 \pm 45.8 \mathrm{nmol} / \mathrm{L}$ and $584.6 \pm 54.2 \mathrm{nmol} / 1$, respectively.

The analysis of the level of plasma concentration of cortisol in the peripheral blood is presented in Table 2.

The study of blood glucose levels in the patients of the first and second clinical groups also revealed a significant difference in the dynamics of its change. The baseline level of the plasma glucose concentration in patients of both clinical groups was comparable to $5.97 \pm 0.64 \mathrm{mmol} / \mathrm{L}$ in the first clinical group and $5.84 \pm 0.76 \mathrm{mmol} / \mathrm{L}$ in the second. Six hours after the surgery, an increase in the level of glycemia in patients of both the first and second clinical groups $(9.24 \pm 1.28 \mathrm{mmol} / \mathrm{L}$ and $6.02 \pm 0.97$ $\mathrm{mmol} / \mathrm{L}$, respectively) was noted, while in the second group the level of glucose did not exceed the upper limit of the norm. One day after the surgical intervention, gradual regression of the glucose concentration level and its return to the norm was registered in the second clinical group $(7.03 \pm 0.34$ $\mathrm{mmol} / \mathrm{L}$ in the first and $5.91 \pm 0.27 \mathrm{mmol} / \mathrm{L}$ in the second), while it should be noted that at all stages of the study in patients of the second clinical group, the level of glycemia underwent less fluctuations.

The amount of trimeperidine used in the first clinical group for the first 24 hours after the operation was $38.6 \pm 2.95 \mathrm{mg}$. In the patients of the

The results of evaluation of the severity of the pain syndrome

Table 1 according to the VAS scale, scores $(M \pm \sigma)$

\begin{tabular}{|c|c|c|c|}
\hline Groups of patients & Observation terms 24 hours before surgery & 6 hours after surgery & 24 hours after surgery \\
\hline I group $(n=38)$ & $3.6 \pm 0.57^{*}$ & $2.9 \pm 0.34^{*}$ & $2.2 \pm 0.35^{*}$ \\
\hline II group $(n=40)$ & $3.4 \pm 0.34 *$ & $1.9 \pm 0.44^{*}$ & $1.5 \pm 0.42 *$ \\
\hline
\end{tabular}

Dynamics of the plasma concentration of cortisol in the peripheral blood, $\mathrm{nmol} / \mathrm{l}(\mathrm{M} \pm \sigma)$

Table 2

\begin{tabular}{|c|c|c|c|c|}
\hline Groups of patients & Observation terms & 24 hours before surgery & 6 hours after surgery & 24 hours after surgery \\
\hline I group $(n=38)$ & & $507 \pm 24.7^{*}$ & $876.1 \pm 76.8^{*}$ & $768.5 \pm 45.8^{*}$ \\
\hline II group $(n=40)$ & & $517.3 \pm 30.8^{*}$ & $676.5 \pm 54.6^{*}$ & $584.6 \pm 54.2^{*}$ \\
\hline
\end{tabular}


Dynamics of the level of glycemia, mmol/l $(\mathrm{M} \pm \sigma)$

\begin{tabular}{|c|c|c|c|c|}
\hline Groups of patients & Observation terms & $\begin{array}{c}24 \text { hours before } \\
\text { surgery }\end{array}$ & $\begin{array}{c}6 \text { hours after } \\
\text { surgery }\end{array}$ & $\begin{array}{c}24 \text { hours after } \\
\text { surgery }\end{array}$ \\
\hline I group $(n=38)$ & & $5.97 \pm 0.64 *$ & $9.24 \pm 1.28^{*}$ & $7.03 \pm 0.34^{*}$ \\
\hline II group $(n=40)$ & & $5.84 \pm 0.76^{*}$ & $6.02 \pm 0.97^{*}$ & $5.91 \pm 0.27^{*}$ \\
\hline
\end{tabular}

second clinical group, the average consumption of this opioid analgesic during the day after the operation was $21.3 \pm 3.17 \mathrm{mg}$. Thus, the prolonged infiltration anesthesia of the surgical intervention area reduced the need for additional administration of trimeperidine by $55.2 \%$.

An analysis of the time of onset of motor activation of patients showed a radical difference of this one of the most important parameters in the studied clinical groups from the point of view of the purpose of the entire treatment. In the first clinical group, the first sitting in the bed and the complete verticalization of the patients in the form of standing up with the support on the crutches occurred $24.8 \pm 2.4$ and $28 \pm 1.4$ hours after the surgery, respectively, which was associated not only with a significant increase in the severity of the pain syndrome in the field of surgical intervention when trying to move in the joint, but also with the presence of a sensory-motor block of the lower limbs developing with each bolus injection of an anesthetic with the prolonged epidural anesthesia. In the second clinical group, the patient's first sitting in the bed was $4.5 \pm 0.5$ hours after the end of the operation; the first verticalization was $6.3 \pm 0.7$ hours after surgery. At the same time, none of the patients of the indicated clinical group noticed any increase in pain in the field of surgical intervention. Thus, the difference in the onset of motor activation of patients was $20.3 \pm 1.4$ hours in favor of patients of the second clinical group. This is, in our opinion, one of the most important advantages of the prolonged infiltration anesthesia of the surgical intervention area, that allows the patient starting the restoration processes of static-dynamic stereotype in the nearest hours of the postoperative period and significantly reducing the risk of a number of postoperative complications (venous thrombosis, pressure ulcers, hypostatic pneumonia).

\section{Discussion}

At present, the concept of ERAS (early recovery after surgery) is becoming urgent in the orthopedic surgery, it is a multidisciplinary standardized perioperative approach, the main objective of which is early and painless mobilization of patients after reconstructive interventions [13]. Within the framework of this concept, for patients undergoing total endoprosthetics of large joints of the lower extremities, a number of clinics have successfully applied the "Caledonian" technique (CALEDonian - Clinical Attitude Leading to Early Discharge), which involves the use of spinal anesthesia and local infiltration anesthesia in the form of a single infiltration anesthesia with a $0.2 \%$ solution of ropivacaine followed by intra-articular infusion of $0.2 \%$ ropivacaine at a rate of $5-8 \mathrm{ml} / \mathrm{h}$ for 48 hours after surgery [12, 13]. Unfortunately, an analytical review of domestic sources reveals a virtually complete lack of experience with the use of this technique in total hip arthroplasty. The overwhelming part of the research works is devoted either to choosing a combination of methods for the most effective intraoperative analgesia, or to evaluating the results of a combination of analgesics in the postoperative period. In this regard, the researches proving the toxic safety of local infiltration of significant volumes of anesthetic, in particular, ropivacaine, with its prolonged introduction into the field of operative intervention in the postoperative period are of great value. [14].

Undoubtedly, the significantly wider field of nociceptive impulse, formed when performing hip arthroplasty in comparison with the knee endoprosthetics, theoretically requires more extensive injection of anesthetic and infiltration of not only intraarticular structures but also paraarticular soft tissues, but our experience has shown that even only intraarticular injection of the drug provided the maximum hermetically sealed joint capsule, leads to a pronounced clinical effect. However, despite the first positive experience with the use of the prolonged infiltration anesthesia in patients with total hip arthroplasty, further studies are needed to determine the optimal rate of administration of the anesthetic, its topical distribution, quantitative and qualitative composition, as well as the possibility of combining with other methods and techniques of anesthesia in the postoperative period.

\section{Conclusions}

1. A comparative analysis of the efficacy of postoperative analgesia and the severity of perioperative stress reaction has shown that the use of the prolonged infiltration anesthesia of the surgical intervention area in the hip replacement 
arthroplasty permits $46.7 \%$ more effectively to control the pain syndrome if compared with the prolonged epidural analgesia and to reduce significantly the endocrine metabolic stress reaction of the organism in the nearest postoperative period.

2. Using the multimodal perioperative analgesia in the scheme of the prolonged infiltration of the surgical intervention area in case of the total hip arthroplasty leads to a decrease in the amount of the required trimeperidine by $55.2 \%$ during the first day of the postoperative period.

3 . The use of the prolonged infiltration anesthesia in the field of operative intervention in the hip replacement arthroplasty in the multimodal perioperative anesthesia scheme allows $20.3 \pm 1.4$ hours earlier initiating motor activation and verticalization of patients, which creates optimal conditions for the effectiveness of further rehabilitation measures and leads to a reduction in the risk of postoperative complications.

\section{Funding}

The work was carried out in accordance with the plan of scientific works of Samara State Medical University. The authors did not receive any support and medical equipment from drug manufacturing companies.

\section{Conflict of interest}

The authors declare that they have no conflict of interest.

\section{Ethics Committee approval}

Approved by the Ethics Committee of Samara State Medical University.

\section{ЛИТЕРАТУРА}

1. Борисов ДБ, Крылов ОВ, Уваров ДН. Периоперационное обезболивание при тотальном эндопротезировании тазобедренного сустава. Анестезиология и Реаниматология. 2009;(4):70-73.

2. Бабаянц АВ, Кириенко ПА, Гельфанд БР. Анестезия при операциях тотального эндопротезирования тазобедренного сустава у пациентов пожилого возраста. Анестезиология и Реаниматология. 2010;(2):66-70.

3. Gerbershagen HJ, Aduckathil S, van Wijck AJ, Peelen LM, Kalkman CJ, Meissner W. Pain intensity on the first day after surgery: a prospective cohort study comparing 179 surgical procedures. Anesthesiology. 2013 Apr;118(4):934-44. doi: 10.1097/ ALN.0b013e31828866b3

4. Зайцев АЮ, Светлов ВА, Козлов СП, Микаелян КП. Фармакология ноцицепции. Анестезиология $u$ реаниматология. 2009;(4):66-69.

5. Загреков ВИ. Регионарная анестезия при эндопротезировании тазобедренного сустава. Регионарная Ане- стезия и Лечение Острой Боли. 2013;7(4):5-13. https:// cyberleninka.ru/article/n/regionarnaya-anesteziya-priendoprotezirovanii-tazobedrennogo-sustava

6. Мукуца ИГ, Царенко СВ, Лядов КВ, Конева ЕС, Волошин АГ. Мультимодальное обезболивание после тотального эндопротезирования тазобедренного сустава. Травматология и Ортопедия России. 2012;(4):72-75. doi: 10.21823/2311-2905-2012--4-72-75.

7. Benhamou D, Berti M, Brodner G, De Andres J, Draisci G, Moreno-Azcoita M, Neugebauer EA, Schwenk W, Torres LM, Viel E. Postoperative Analgesic Therapy Observational Survey (PATHOS): a practice pattern study in 7 central/southern European countries. Pain. 2008 May;136(1-2):134-41.

8. Овечкин АМ, Бастрикин СЮ. Протокол спинально-эпидуральной анестезии и послеоперационной эпидуральной анальгезии при операциях тотального эндопротезирования крупных суставов нижних конечностей. Регионарная Анестезия и Лечение Острой Боли. 2007;1(1):79-81.

9. Rawal N. Epidural technique for postoperative pain: gold standard no more? Reg Anesth Pain Med. 2012 MayJun;37(3):310-7. doi: 10.1097/AAP.0b013e31825735c6 10. Ilfeld BM, Duke KB, Donohue MC. The association between lower extremity continuous peripheral nerve blocks and patient falls after knee and hip arthroplasty. Anesth Analg. 2010 Dec;111(6):1552-54. doi: 10.1213/ANE.0b013e3181fb950

11. Werner MU, Mjöbo HN, Nielsen PR, Rudin A. Prediction of postoperative pain: a systematic review of predictive experimental pain studies. Anesthesiology. 2010 Jun;112(6):1494-502. doi: 10.1097/ ALN.0b013e3181dcd5a

12. Kerr DR, Kohan L. Local infiltration analgesia: a technique for the control of acute postoperative pain following knee and hip surgery: a case study of 325 patients. Acta Orthop. 2008 Apr;79(2):174-83. doi: 10.1080/17453670710014950

13. Place K, Scott NB. Enhanced recovery for lower limb arthroplasty. Continuing Education in Anaesthesia Critical Care and Pain (CEACCP). 2014 Jun;14(Is 3,1):95-99. https://doi.org/10.1093/bjaceaccp/mkt037 14. Корячкин ВА, Гераськов ЕВ, Коршунов ДЮ. Оценка безопасности инфильтрационной анестезии при тотальном эндопротезировании коленного сустава. Новости Хирургии. 2015;23(4):436-39. doi:10.18484/2305-0047.2015.4.436

\section{REFERENCES}

1. Borisov DB, Krylov OV, Uvarov DN. Perioperative analgesia during total hip replacement. Anesteziologiia $i$ Reanimatologiia. 2009;(4):70-73. (in Russ.)

2. Babaiants AV, Kirienko PA, Gel'fand BR. Anesteziia pri operatsiiakh total'nogo endoprotezirovaniia tazobedrennogo sustava u patsientov pozhilogo vozrasta. Anesteziologiia i Reanimatologiia. 2010;(2):66-70. (in Russ.)

3. Gerbershagen HJ, Aduckathil S, van Wijck AJ, Peelen LM, Kalkman CJ, Meissner W. Pain intensity on the first day after surgery: a prospective cohort study comparing 179 surgical procedures. Anesthesiology. 2013 Apr;118(4):934-44. doi: 10.1097/ ALN.0b013e31828866b3

4. Zaitsev AYu, Svetlov VA, Kozlov SP, Mikayelyan KP. Pharmacology of nociception. Anesteziologiia $i R e-$ animatologiia. 2009;(4):66-69. (in Russ.)

5. Zagrekov VI. Regional anesthesia for total hip arthroplasty. Regionarnaia Anesteziia $i$ Lechenie Ostroi 
Boli. 2013;7(4):5-13. https://cyberleninka.ru/article/n/ regionarnaya-anesteziya-pri-endoprotezirovanii-tazobedrennogo-sustava. (in Russ.)

6. Mukutsa IG, Tsarenko SV, Lyadov KV, Koneva ES, Voloshin AG. Multimodal analgesia after total hip arthroplasty. Travmatologiia $i$ Ortopediia Rossii. 2012;(4):72-75. doi: 10.21823/2311-2905-2012--4-7275. (in Russ.)

7. Benhamou D, Berti M, Brodner G, De Andres J, Draisci G, Moreno-Azcoita M, Neugebauer EA, Schwenk W, Torres LM, Viel E. Postoperative Analgesic Therapy Observational Survey (PATHOS): a practice pattern study in 7 central/southern European countries. Pain. 2008 May;136(1-2):134-41.

8. Ovechkin AM, Bastrikin SIu. Protokol spinal'noepidural'noi anestezii i posleoperatsionnoi epidural'noi anal'gezii pri operatsiiakh total'nogo endoprotezirovaniia krupnykh sustavov nizhnikh konechnostei. Regionarnaia Anesteziia i Lechenie Ostroi Boli. 2007;1(1):79-81. (in Russ.)

9. Rawal N. Epidural technique for postoperative pain: gold standard no more? Reg Anesth Pain Med. 2012 MayJun;37(3):310-7. doi: 10.1097/AAP.0b013e31825735c6

\section{Адрес для корреспонденции}

443099, Российская Федерация,

г. Самара, ул. Чапаевская, 89,

Самарский государственный

медицинский университет,

кафедра травматологии,

ортопедии и экстремальной хирургии

им. акад. РАН А.Ф. Краснова,

тел.: +79276076209,

e-mail: dr.kudashev@gmail.com,

dmitrykudashew@mail.ru,

Кудашев Дмитрий Сергеевич

\section{Сведения об авторах}

Котельников Геннадий Петрович, академик РАН, д.м.Н., профессор, заведующий кафедрой травматологии, ортопедии и экстремальной хирургии имени академика РАН А.Ф. Краснова, Самарский государственный медицинский университет, г. Самара, Российская Федерация.

https://orcid.org/0000-0001-7456-6160

Ларцев Юрий Васильевич, д.м.н., заведующий травматолого-ортопедическим отделением №2 Клиник Самарского государственного медицинского университета, профессор кафедры травматологии, ортопедии и экстремальной хирургии имени академика РАН А.Ф. Краснова, Самарский государственный медицинский университет, г. Самара, Российская Федерация.

https://orcid.org/0000-0003-4450-2486

Труханова Инна Георгиевна, д.м.н., профессор, заведующая кафедрой анестезиологии, реаниматологии и скорой медицинской помощи Института профессионального образования, Самарский государственный медицинский университет, г. Самара, Российская Федерация.

https://orcid.org/0000-0002-2191-1087

Гуреев Антон Дмитриевич, заведующий отделением анестезиологии-реанимации Клиник Самарского государственного медицинского университета,
10. Ilfeld BM, Duke KB, Donohue MC. The association between lower extremity continuous peripheral nerve blocks and patient falls after knee and hip arthroplasty. Anesth Analg. 2010 Dec;111(6):1552-54. doi: 10.1213/ ANE.0b013e3181fb9507

11. Werner MU, Mjöbo HN, Nielsen PR, Rudin A. Prediction of postoperative pain: a systematic review of predictive experimental pain studies. Anesthesiology. 2010 Jun;112(6):1494-502. doi: 10.1097/ ALN.0b013e3181dcd5a0

12. Kerr DR, Kohan L. Local infiltration analgesia: a technique for the control of acute postoperative pain following knee and hip surgery: a case study of 325 patients. Acta Orthop. 2008 Apr;79(2):174-83. doi: $10.1080 / 17453670710014950$

13. Place K, Scott NB. Enhanced recovery for lower limb arthroplasty. Continuing Education in Anaesthesia Critical Care and Pain (CEACCP). 2014 Jun;14(Is 3,1):95-99. https://doi.org/10.1093/bjaceaccp/mkt037

14. Koriachkin VA, Geras'kov EV, Korshunov DIu. Evaluation of Infiltration Anesthesia Safety in Total Knee Joint Arthroplasty. Novosti Khirurgii. 2015;23(4):436-39. doi:10.18484/2305-0047.2015.4.436 (in Russ.)

\section{Address for correspondence}

443099, The Russian Federation, Samara, Chapayevskaya Str., 89, Samara State Medical University, Department of Traumatology, Orthopedics and Extreme Surgery named after Acad. of RAS A.F. Krasnov, Tel.: +79276076209, e-mail: dr.kudashev@gmail.com, dmitrykudashew@mail.ru, Dmitrij S. Kudashev

\section{Information about the authors}

Kotelnikov Gennady P., Academician of RAS, MD, Professor, Head of the Department of Traumatology, Orthopedics and Extreme Surgery named after Acad. of RAS A.F. Krasnov, Samara State Medical University, Samara, Russian Federation.

https://orcid.org/0000-0001-7456-6160

Lartsev Yuri V., MD, Head of the Traumatology and Orthopedics unit №2 of Clinic of Samara State Medical University, Professor of the Department of Traumatology, Orthopedics and Extreme Surgery named after Acad. of RAS A.F. Krasnov, Samara State Medical University, Samara, Russian Federation.

https://orcid.org/0000-0003-4450-2486

Trukhanova Inna G., MD, Head of the Department of Anesthesiology, Reanimatology and Emergency Medical Care of the Institute of Vocational Education, Samara State Medical University, Samara, Russian Federation. https://orcid.org/0000-0002-2191-1087

Gureev Anton D., Head of the AnaesthesiologyResuscitation Unit of Clinic of Samara State Medical University, Assistant of the Department of Anesthesiology, Reanimatology and Emergency Medical Care of the Institute of Vocational Education, Samara State Medical University, Samara, Russian Federation.

https://orcid.org/0000-0001-8389-7244

Firstova Ol'ga V., Anesthetist-Resuscitator of the 
ассистент кафедры анестезиологии, реаниматологии и скорой медицинской помощи Института профессионального образования, Самарский государственный медицинский университет, г. Самара, Российская Федерация.

https://orcid.org/0000-0001-8389-7244

Фирстова Ольга Валерьевна, врач анестезиолог-реаниматолог отделения анестезиологии-реанимации Клиник Самарского государственного медицинского университета, г. Самара, Российская Федерация. https://orcid.org/0000-0002-8920-0433

Кудашев Дмитрий Сергеевич, к.м.н., врач травматолог-ортопед травматолого-ортопедического отделения №2 Клиник Самарского государственного медицинского университета, ассистент кафедры травматологии, ортопедии и экстремальной хирургии имени академика РАН А.Ф. Краснова, Самарский государственный медицинский университет, г. Самара, Российская Федерация.

https://orcid.org/0000-0001-8002-7294

\section{Информация о статье}

Получена 6 сентября 20172.

Принята в печать 26 февраля 2018 г. Доступна на сайте 15 июня 2018 г.
Anaesthesiology-Resuscitation Unit of Clinic of Samara State Medical University, Samara, Russian Federation. https://orcid.org/0000-0002-8920-0433

Kudashev Dmitrij S., MD, Traumatologist-Orthopedist of the Traumatology and Orthopedics unit №2 of Clinics of Samara State Medical University, Assistant of the Department of Traumatology, Orthopedics and Extreme Surgery named after Acad. of RAS A.F. Krasnov, Samara State Medical University, Samara, Russian Federation. https://orcid.org/0000-0001-8002-7294

\section{Article history}

Arrived 6 September 2017

Accepted for publication 26 February 2018

Available online 15 June 2018 